Canadian Journal of Higher Education Revue canadienne d'enseignement supérieur

Volume 43, No. 3, 2013, pages i-iii

\title{
Introduction from special issue editors
}

\section{Blended and online higher education: teaching and learning in a wired world}

Martha Cleveland-Innes

Athabasca University

Heather Kanuka

University of Alberta

What research direction is needed in the scholarship of teaching and learning in higher education? Over a decade ago, Windschitl (1998) advocated for more research on increasing student inquiry through the World Wide Web and illuminating web-based student communication. The release and then extensive development of a model of online communities of inquiry (Garrison, Anderson, \& Archer, 2000) responded to Windschitl's call. In addition to continued work in these two areas, a stronger research focus on learning theory and everyday use of Web 2.0 technologies is required (Greenhow, Robelia, \& Hughes, 2009; Zawacki-Richter, Anderson, \& Tunca, 2010).

This special issue presents research on education access and quality learning experiences afforded by online education delivery, in addition to research on use of the Internet for interaction and collaborative engagement. What changes are required to the role of students and the role of faculty members to allow access and engagement in online and blended learning and teaching? What leadership actions, reward structures, support services, and technology training and maintenance will take us to new places in the foundations of teaching and learning? The five papers in this special issue respond to these questions, as well as to other issues related to blended and online teaching and learning in institutions of higher education.

The first paper in this special issue, "Student Approaches to Learning in Relation to Online Course Completion," explores approaches to studying and course completion in two online preparatory university courses in mathematics and computer programming. Students participating in these courses ( $\mathrm{n}=493)$ answered a short version of the Approaches and Study Skills Inventory for Students. Results show that students demonstrating a deep approach to learning are more likely to complete their courses. In the mathematics 
course, a combination of deep and strategic approaches correlates positively with course completion. In the programming course, students who demonstrate a surface approach are less likely to complete.

The second paper, "Using Blended Learning Strategies to Address Teaching Development Needs: How Does Canada Compare?," investigates blended learning strategies that can be used to assist academics in the higher education sector with the knowledge, skills, and abilities required for effective teaching with technology. In Canada, at present, assisting teaching staff in institutions of higher education is a challenge for teaching centres. The aim of this study was to determine whether this is an ongoing issue unique to Canada and, if not, whether teaching centres might be able to implement different or more effective strategies based on what others outside of Canada are doing. Teaching centre leaders in Australia, Finland, Sweden, Denmark, Britain, Scotland, and the United States $(n=31)$ were interviewed to explore how their units used blended learning strategies. The outcomes of this study confirm that, as in Canada, there is a "value gap" between academics and leaders of teaching centres regarding teaching development initiatives using blended learning strategies.

The third paper, "Online Graduate Student Identity and Professional Skills Development," presents preliminary qualitative findings from a project that developed, offered, and evaluated graduate student professional skills in an online format. The findings in this study suggest that while online graduate students can develop professional skills while navigating their studies, building relationships, and participating in online learning communities, they would also like to develop such professional skills in a more deliberate way. The outcomes of this study provide a comprehensive description of these approaches.

The fourth paper, "Investigating the Role of Mobile Devices in a Blended Pre-Service Teacher Education Program," investigates how mobile devices can be used to support the required program outcomes in a blended pre-service teacher education degree. For this study, student online surveys were used for data collection, followed by a focus group interview. The outcomes reveal that mobile devices do indeed add value for supporting future professional responsibilities (e.g., career-long learning, collaboration) and facilitating student learning. The data also indicate that these devices are less effective for planning, assessment, and managing the classroom environment.

The final paper in this special issue, "The VIRI (Virtual, Interactive, Real-Time, Instructor-Led) Classroom: The Impact of Blended Synchronous Online Courses on Student Performance, Engagement, and Satisfaction," investigated the impact of teaching a blended course, using a VIRI classroom, on student engagement, performance, and satisfaction. This study used an experimental design with both a control group and a treatment group with a randomized sample of 90 students. Pre- and post-semester questionnaires were used to measure student engagement, performance, and satisfaction. The results of this study revealed no statistical differences in student performance between the control and treatment groups. The only student engagement factor with a statistically significant difference between groups was students' interest in their courses. Additional findings of this study provide guidance for instructors interested in the ways a VIRI classroom can leverage the capabilities of technology without compromising learning outcomes. 


\section{References}

Garrison, D. R., Anderson, T., \& Archer, W. (2000). Critical inquiry in a text-based environment: Computer conferencing in higher education. The Internet and Higher Education, 2(2-3), 87-105.

Greenhow, C., Robelia, E., \& Hughes, J. (2009). Research on learning and teaching with web 2.0: Bridging conversations. Educational Researcher, 38(4), 280-283

Windschitl, M. (1998). The WWW and classroom research: What path should we take? Educational Researcher, 27(1), 28-33.

Zawacki-Richter, O., Anderson, T., \& Tuncay, N. (2010). The growing impact of open access distance educationjournals: A bibliometric analysis. Journal of Distance Education, 24(3). Retrieved from http://www.jofde.ca/index.php/jde/article/viewArticle/661/1170

\section{Contact Information}

Martha Cleveland-Innes

Centre for Distance Education

Athabasca University

martic@athabascau.ca

Heather Kanuka

Faculty of Education

University of Alberta

hakanuka@ualberta.ca 